\title{
Aggressive breast cancer in western Kenya has early onset, high proliferation, and immune cell infiltration
}

\author{
Rispah T. Sawe ${ }^{1,2,3,4}$, Maggie Kerper ${ }^{1,2}$, Sunil Badve ${ }^{2,5}$, Jun Li ${ }^{1,2}$, Mayra Sandoval-Cooper ${ }^{1,2}$, Jingmeng Xie ${ }^{1,2,6}$, \\ Zonggao Shi ${ }^{2}$, Kirtika Patel ${ }^{3}$, David Chumba ${ }^{3}$, Ayub Ofulla ${ }^{4}$, Jenifer Prosperi ${ }^{1,2,5,7}$, Katherine Taylor ${ }^{1,6}$, \\ M. Sharon Stack ${ }^{1,2,5}$, Simeon Mining ${ }^{3}$ and Laurie E. Littlepage ${ }^{1,2,5^{*}}$
}

\begin{abstract}
Background: Breast cancer incidence and mortality vary significantly among different nations and racial groups. African nations have the highest breast cancer mortality rates in the world, even though the incidence rates are below those of many nations. Differences in disease progression suggest that aggressive breast tumors may harbor a unique molecular signature to promote disease progression. However, few studies have investigated the pathology and clinical markers expressed in breast tissue from regional African patient populations.

Methods: We collected 68 malignant and 89 non-cancerous samples from Kenyan breast tissue. To characterize the tumors from these patients, we constructed tissue microarrays (TMAs) from these tissues. Sections from these TMAs were stained and analyzed using immunohistochemistry to detect clinical breast cancer markers, including estrogen receptor (ER), progesterone receptor (PR), human epidermal growth factor 2 receptor (HER2) status, Ki67, and immune cell markers.

Results: Thirty-three percent of the tumors were triple negative (ER-, PR-, HER2-), $59 \%$ were ER+, and almost all tumors analyzed were HER2-. Seven percent of the breast cancer patients were male, and $30 \%$ were $<40$ years old at diagnosis. Cancer tissue had increased immune cell infiltration with recruitment of CD163+ (M2 macrophage), CD25+ (regulatory T lymphocyte), and CD4+ (T helper) cells compared to non-cancer tissue.

Conclusions: We identified clinical biomarkers that may assist in identifying therapy strategies for breast cancer patients in western Kenya. Estrogen receptor status in particular should lead initial treatment strategies in these breast cancer patients. Increased CD25 expression suggests a need for additional treatment strategies designed to overcome immune suppression by CD25+ cells in order to promote the antitumor activity of CD8+ cytotoxic T cells.
\end{abstract}

Keywords: Kenya, Breast cancer, Estrogen receptor, CD163, CD25

\section{Background}

Breast cancer is the most frequently diagnosed and the most deadly cancer among women worldwide, taking roughly half a million lives per year [1]. Between 1980 and 2010, the global rate of breast cancer incidence increased 2.6 times (i.e., from 641,000 to $1,643,000$ patients) [2].

\footnotetext{
* Correspondence: laurie.littlepage@nd.edu

'Deceased

'University of Notre Dame, Notre Dame, IN, USA

${ }^{2}$ Harper Cancer Research Institute, University of Notre Dame, 1234 N Notre Dame Avenue, South Bend, IN, USA

Full list of author information is available at the end of the article
}

Unfortunately, the global rates of breast cancer incidence and mortality continue to increase, particularly in developing countries [2]. In fact, $59 \%$ of the worldwide breast cancer deaths is estimated to occur in developing countries [1].

Similar to global cancer trends, breast cancer is the most highly diagnosed and leading cause of cancer deaths in women throughout Africa (63,100 deaths in 2012) [3]. However, in Africa, noncommunicable diseases like cancer are not considered as pressing of a burden to society as infectious diseases, which have a higher prevalence in the 
patient population. Limited resources for surveillance, treatment, and research, as well as low public awareness campaigns for early detection and treatment affect the rate of cancer diagnosis. In addition, most standard care and treatments used globally for treating breast cancer are derived from research on patient populations in resourcerich developed countries, which results in challenging implementation strategies in resource-poor countries $[4,5]$.

Even within developed countries, breast cancer disease etiology and progression can be quite heterogeneous across patient populations. In contrast to global increases in breast cancer incidence and mortality, the U.S. breast cancer mortality declined as much as $34 \%$ since 1990 $[6,7]$. This decline is not consistent across patient groups and varies significantly by race/ethnicity. NonHispanic white women have the highest incidence of breast cancer, while African American women have both the highest mortality rate (30.8 deaths per 100,000 females) compared to non-Hispanic white females $(22.7$ deaths per 100,000) as well as the lowest 5-year causespecific survival $(78.9 \%)$ compared to non-Hispanic whites $(88.6 \%)$.

Contributing to the differences in mortality rates, African American women in the U.S. develop breast cancer with a higher grade and a higher representation of early-onset, high-grade, node-positive, and hormone receptor-negative tumors than do patients of other races [8]. A decreased five-year survival rate for African Americans is associated with the pathological presentation at diagnosis but not with patient age or treatment differences [9]. Across age groups, African American women commonly develop tumors that are diagnosed beyond stage I, and African American women who present with stage I disease also have a higher death rate than matched white women [10].

While the striking racial differences in mortality are due in part to differential access to health care for both early detection and treatment of disease, these statistics also reflect the differential incidence of molecular subtypes of breast cancer with poor prognosis across patient populations. Underlying genetic differences across patient populations may harbor unique molecular signatures that result in racial disparities in prognosis and response to treatment. For example, estrogen receptor (ER) status is differentially expressed across racially diverse patient populations. In the U.S., even though African Americans and Hispanics have a higher incidence of ERbreast cancer than is seen in non-Hispanic whites, the majority of African American breast tumors are ER+ [11]. In contrast, tumors from Africa have more heterogeneity. Tumors from breast cancer patients in Nigeria and Senegal were predominantly ER- [12-14], while tumors from another group of patients in Nigeria were predominantly ER+ [15]. Identification of additional molecular markers of breast cancer will help us to understand regional differences that are relevant to disease etiology and treatment.

Of African countries, Kenya has among the highest risk of breast cancer [3]. Breast cancer incidence and mortality rates also have increased significantly since 1980 rates [3]. The goal of our research is to begin to identify underlying molecular mechanisms that promote Kenyan breast cancer by comparing our patient population to patients from Kenya, other parts of East Africa, and African Americans. In this study, we identify the expression patterns of clinical markers in a western Kenyan patient population not studied previously. For this analysis, we selected a patient population from the Moi Teaching and Referral Hospital patient population because previous Kenyan studies looking at the clinical markers of breast cancer were completed in Nairobi, which is a larger metropolis and has different ethnic group demographics, environmental variables, and ethnic groups than the regional areas of Eldoret. A better characterization of the regional differences in breast cancer will guide the creation of early detection programs and effective treatment strategies designed to reduce the cancer mortality rates and suffering in both African and related patient populations.

\section{Methods}

\section{Patient samples and geographic region}

These studies follow appropriate ethical standards and are in accordance with and have been approved by IRBs from both the University of Notre Dame (IRB Approval \# 13-06-1102) and Moi University (IRB Approval \# 000655). The tissue samples were collected with patient consent at Moi Teaching and Referral Hospital (MTRH), which is the primary academic hospital that serves the entire western Kenya community and is located in the city of Eldoret town (population: 289,380), Uasin Gishu district, North of Rift Valley province of Kenya. Uasin Gishu County is home to 894,179 people. Therefore, the the catchment area for MTRH is a fairly large community and represents a large population. Eldoret is surrounded by agricultural regions and is $330 \mathrm{~km}$ northwest of Nairobi. The significant distance between Eldoret and Nairobi makes MTRH a highly utilized hospital facility. As a regional hospital, MTRH treats patients not only from western Kenya but also from eastern Uganda and southern Sudan. Accruing patient samples from one hospital is common in related population-focused studies (e.g., [16-19]).

\section{Study design}

This was a prospective study in which samples were collected consecutively. All breast cancer patients who consented to participation in this study and who attended the MTRH oncology clinic between May 2011 and July 2013 were included in this study (Table 1). The 
Table 1 Clinical characteristics of Western Kenya patient population

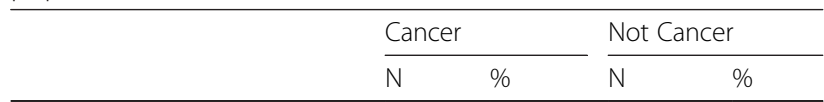

Cancer status

Cancer Tissue
Not Cancer Breast Tissue
Other Tissue
Total (N)

$\begin{array}{llll}68 & 100 & 0 & 0 \\ 0 & 0 & 89 & 87 \\ 0 & 0 & 13 & 13 \\ 68 & & 102 & \end{array}$

Gender

Male

Female

Total (N)

Age at diagnosis

$<40$ years

40-49 years

$\geq 50$ years

Total (N)

HER2 status

Positive

Total (N)

Estrogen receptor status

Positive
Negative
Total (N)
Progesterone receptor status
Positive

Negative 29

Total (N) 48

Triple negative (ER-, PR-, $\quad 16$ HER2-)

Total (N)

Status

$\begin{array}{ll}\text { Died } & 11 \\ \text { Alive } & 5 \\ \text { Total }(\mathrm{N}) & 16 \\ \text { Tribe } & \end{array}$

$\begin{array}{lll}\text { Luyha } & 11 & 38 \\ \text { Kalenjin } & 10 & 34 \\ \text { Kikuyu } & 4 & 14 \\ \text { Luo } & 3 & 10 \\ \text { Teso } & 1 & 3 \\ \text { Total (N) } & 29 & \end{array}$

Hormone-based Contraception

Single agent (Injected or Pill) $11 \quad 50$

Combined (Injected and Pill) $2 \quad 9$
Table 1 Clinical characteristics of Western Kenya patient population (Continued)

\begin{tabular}{lll}
\hline Neither & 9 & 41 \\
Total $(\mathrm{N})$ & 22 & \\
Marriage & & \\
$\quad$ Married or widowed & 24 & 92 \\
Not Married & 2 & 8 \\
Total (N) & 26 & \\
Median age (years) & 48.5 years $(N=38)$ & 31 years old $(N=9)$ \\
Mean age (years) & 51.9 years $(N=38)$ & 35.6 years $(N=9)$ \\
\hline
\end{tabular}

patients included in this study were included in this study after informed consent and had either nonmalignant lumps or clinically established breast cancer (both women and men). The patients had no history of other cancers and no history of chemotherapy prior to diagnosis. The patients who were excluded from the study included patients who did not provide consent, those with a history of other cancer, and those who had a history of treatment with chemotherapy. Using non-cancer tissue from the control population was an important control for the immune cell analysis to provide a baseline comparison of our analysis of the immune cells in cancer tissue to normal tissue in Kenyan breast tissue. In Kenya, breast reduction surgery for cosmetic reasons is uncommon, making it difficult to get true normal tissue. Benign tissues with a normal pathology are typical controls in immune cell quantification analysis when establishing differences in cell populations between cancer vs. not cancer samples [20,21].

Each patient also volunteered clinical data, including a family history of breast cancer or related cancers, saliva was collected, and tumors were obtained from surgical procedures, including mastectomies. Secondary data including HIV status and other medical conditions were extracted from the patients' files. Incomplete clinical data for the patients was assembled for the patients included in this study. Clinical data was collected from both a questionnaire and from patient records. A questionnaire was administered to all patients who consented to be a part of this study. This enabled collection of the following information: demographic characterization, name, age, gender, nationality, ethnic group, place of birth, village location, county, marital status, weight, and height. Patients also provided information on disease status, when diagnosis was made, treatment, tumor characteristics, left or right, axillary lymph nodes palpability, family history, and risk factors that included age at first menarche, number of pregnancies, breast feeding, use of oral or injective contraceptives, use of HRT, smoking, alcohol consumption, and other environmental factors. 
MTRH is the only hospital in western Kenya that is in the AMPATH consoritum. AMPATH promotes care, training, and research as part of its mission and allows "Kenyan leaders to draw upon the resources and talents of North American academic health institutions to tackle the challenges of disease and poverty" (AMPATH website). By being part of the AMPATH consortium, these Kenyan institutions have received extensive training and equipment from these universities. The AMPATH consortium is led by Indiana University and includes multiple universities and academic medical centers in North America.

\section{Tissue fixation and processing}

Harvested specimens were fixed in $10 \%$ neutral buffered formalin, then routinely processed in a Leica TP 1020 tissue processor (Leica Microsystems Inc., Nussloch Gmbh Heidelbeger Nussloch Germany), and paraffin embedded in Paraplast X-tra (McCormick ${ }^{\text {tix }}$ Scientific). The embedded tissue blocks were transferred from the MTRH hospital to the University of Notre Dame and submitted for further studies following IRB approval from both institutions. The Kenyan tissue samples were subsequently melted down and re-embedded in Surgipath EM_400 paraffin (Leica Biosystems Inc.), using a Sakura Tissue TEK5 embedding station. Paraffin sections for all studies were cut at 3-4 $\mu \mathrm{m}$ in thickness on a Leica RM2125-RTS rotary microtome for hematoxylin and eosin (H\&E) and immunohistochemical staining.

\section{Pathology}

The $3 \mu \mathrm{m}$ cut tissue slides were stained with Hematoxylin \& Eosin (Richard Allan Scientific; Kalamazoo, MI) and submitted for blinded microscopic examinations by a U.S. board certified breast pathologist (S.B.), a Kenyan pathologist (D.C.), and a Ph.D. research pathologist (Z.S.).

\section{Tissue microarrays}

Tissue microarrays (TMAs) were constructed from the cancer and non-cancer breast tissue samples. Tissue cores were punched from donor blocks with a $1 \mathrm{~mm}$ diameter stylus and loaded to recipient blocks. Distance between tissue cores was also set at $1 \mathrm{~mm}$. The TMA layout on the recipient TMA blocks was predesigned to represent and distribute randomly across the TMA blocks, the patient heterogeneity (i.e., cancer and non-cancer) as identified by pathology. The specific regions of the blocked tissues selected for the TMA cores were based on the pathology diagnoses from the H\&E stained slides. The regions of interest for each block was marked by a pathologist as guidance for core extraction. TMA blocks were constructed with Veridiam Advanced Tissue Arrayer VTA-110CC. Each of the two TMA constructed blocks used for the staining had 100 tissues per block with duplicates across the two TMA blocks. A representative group of 92 tissue samples were included on both of the constructed TMA blocks.

\section{Staining by immunohistochemistry (IHC)}

The TMA blocks were sectioned onto Flex IHC slides (Dako, Inc.), deparaffinized and hydrated, followed by antigen retrieval in the PT Linker (Dako, Inc.). The slides were stained for the indicated antibody and antigen retrieval conditions summarized in Additional file 1: Table S1. The IHC staining was processed on a Dako Cytomation Autostainer Plus. And followed with a Hematoxylin nuclear counterstain (Dako, Inc.). For quality control purposes, known positive control and negative control specimens were included for each antibody set.

\section{Image scanning and analysis}

The slides were digitally scanned at a 200X magnification on an Aperio ScanScope CS whole slide scanner (Leica, Biosystems, Inc.). The generated digital images were saved onto the eSlide Manager database (ver. 12.0.1.5027).

To quantify the area of positive staining and density or the number of cells stained with $D A B$ chromagen, customized macros for each stain were generated from the Color Deconvolution and Cell Quantification algorithms in the Aperio Image Analysis Tools software. All the cores and regions of interest on each TMA slide were labelled and submitted for analysis with a proper validated macro for each stain. The output results, included percentage of positively stained area and density or positive stained cell numbers of each intensity levels, respectively. The mark up core images were re-evaluated, and the generated data were exported from ImageScope annotation files as an Excel file for statistical analyses. The scored regions of each sample were checked manually to see if the algorithms had false positives or false negatives. The sample was not included if $>10 \%$ of the cells were misclassified.

\section{Statistical analysis}

Cancer and non-cancer ("not cancer") samples were compared by Mann-Whitney nonparametric analysis using Prism software. All the tests used a confidence interval of $95 \%(\alpha=0.05)$.

To compare the ER status in our data and in METABRIC data [22] while taking age into account, we used the following logistic regression model: 


$$
\operatorname{logit}\left(\pi_{\mathrm{ER}-}\right)=\beta_{0}+\beta_{1} \cdot \text { age }+\beta_{2} \cdot I(\text { our data or not })
$$

In the model, $\pi_{\mathrm{ER}-}$ is the probability of ER-, age is the age of the patient at diagnosis, and $I$ (our data or not) equals 1 if the patient is from our data, and 0 if the patient is from the METABRIC data. Note that this model means that for a patient in METABRIC data, logit $\left(\pi_{\mathrm{ER}}-\right)=\beta_{0}+\beta_{1}$ - age, and for a patient in our data, logit $\left(\pi_{\mathrm{ER}-}\right)=\beta_{0}+\beta_{1}$. age $+\beta_{2}$. Therefore, to test whether the ER status is different in the two datasets while taking age into account, we tested $H_{0}: \beta_{2}=0$ vs $H_{A}: \beta_{2} \neq 0$. The p-value was $P=0.11$, which is not significant. This indicates that the different ER-proportions in the two datasets is likely caused by the age difference in the two populations. (Also, our model confirms that age has a very significant effect on ER status: $\beta_{1} \neq 0$ with $p$-value $<1 \times 10^{-10}$.)

\section{Results}

\section{Young age at diagnosis for breast cancer patients in western Kenya}

To characterize the breast cancer seen in western Kenya, we first collected, processed, and sectioned 170 primary breast tissue samples collected at the Moi Teaching and Referral Hospital, Eldoret, Kenya (Fig. 1a). For an initial pathological diagnosis based on morphological criteria, we used hematoxylin and eosin (H\&E) stained tissue sections from each patient's tumor tissue. From the pathology analysis, we grouped the patient tissues into cancer and not cancer categories. Based on this analysis, we excluded patient samples that were not breast tissue, were inconclusive, or were of low quality based on the pathology. The remaining samples included 68 cancer and 89 not cancer tumor tissue samples.

The Kenyan breast cancer patients who participated in this study included a diverse group of patients ranging from age 16 to 84 (Table 1). The median age at diagnosis for the Kenyan breast cancer patient cohort was 48.5 years, and the mean age was 51.9 years, which are both younger than the mean age at diagnosis of U.S.-born white breast cancer patients (64.1 years of age), U.S.-born black breast cancer patients (59.1 years), or Jamaica-born black breast cancer patients (56.5 years) who live in the U.S. [23]. This mean age at diagnosis of this Kenyan cohort is similar in age to both Western Africa-born black breast cancer patients (48 years) and Eastern-Africa born black breast cancer patients (48 years) who live in the U.S. [23].

Fifty-eight of the 68 patients with cancer provided gender information. The breast cancer patients were $93 \%$ female and $7 \%$ male (i.e., 4 of 58 cancer patients). The rate of male breast cancer is higher in this population than the one percent rate seen in the U.S. [24] and in other East African studies (Table 2) [17, 19, 25-29]. For additional analysis, we applied a Fisher's exact test to test whether our study has a larger proportion of male breast cancer patient than is seen in other geographic regions. The percentage of male breast cancer patients was significantly different from other large breast cancer population studies from Tunisia, Nigeria, and the United States ( $>1437$ patients) (Additional file 2: Table S2). This suggests that the difference in percentage of male patients is unlikely due to chance alone. We also compared our patient population with smaller studies collected in Kenya, Uganda, Tunisia, and Zimbabwe. While the number of male breast cancer patients seen in our Kenyan patient population did not reach statistical significance, the lack of statistical significance in these studies may be due to the smaller sample sizes.

Moreover, the patients predominantly come from two ethnic groups (i.e., Luyha and Kelenjin), are married, and have no known familial history of breast cancer. More than half of the patients used either injected or pill contraceptives.

\section{Breast cancer pathologies are predominantly invasive ductal carcinoma}

We next examined the pathologies of the breast tissue samples using $H \& E$ tissue sections from each tumor. Invasive ductal carcinoma was the predominant pathology seen in the malignant tumors (79 \% of cancer tissues) (Fig. 1b). Additional pathologies represented in the patient population also included mucinous carcinoma, Paget's disease, adenocarcinoma, invasive carcinoma, lobular carcinoma, invasive lobular carcinoma, papillary carcinoma, invasive cribiform carcinoma, and undifferentiated carcinoma or sarcoma. Some of these tumors had significant inflammatory infiltration or mucinous pathologies associated with the carcinoma (Fig. 1c).

The pathologies of the non-malignant tissues included normal breast tissue as well as fibroadenoma and adenosis, fibrocystic disease, ductal hyperplasia, atypical ductal hyperplasia, apocrine metaplasia (not cancer), intraductal papilloma, papillary hyperplasia, tubular adenoma, and lobular hyperplasia (Fig. 1b). Only one sample had the pathology of ductal carcinoma in situ.

\section{Kenyan breast cancer samples are HER2 negative and are heterogeneous for ER and PR expression}

We next scored and quantified the clinical markers expressed in the breast tumor tissues collected for this study. We analyzed the patient tissue samples for expression of clinical markers of breast cancer (e.g., HER2, estrogen receptor/ER, and progesterone receptor/PR) using tissue microarrays (TMAs) we generated from the patient breast tissue blocks. We first stained and scored TMA sections for the receptor HER2 by immunohistochemistry (Fig. 2a). Eighty-six percent of the cancer samples were negative for HER2 expression. This distribution is similar to that seen in the USA and western countries. 

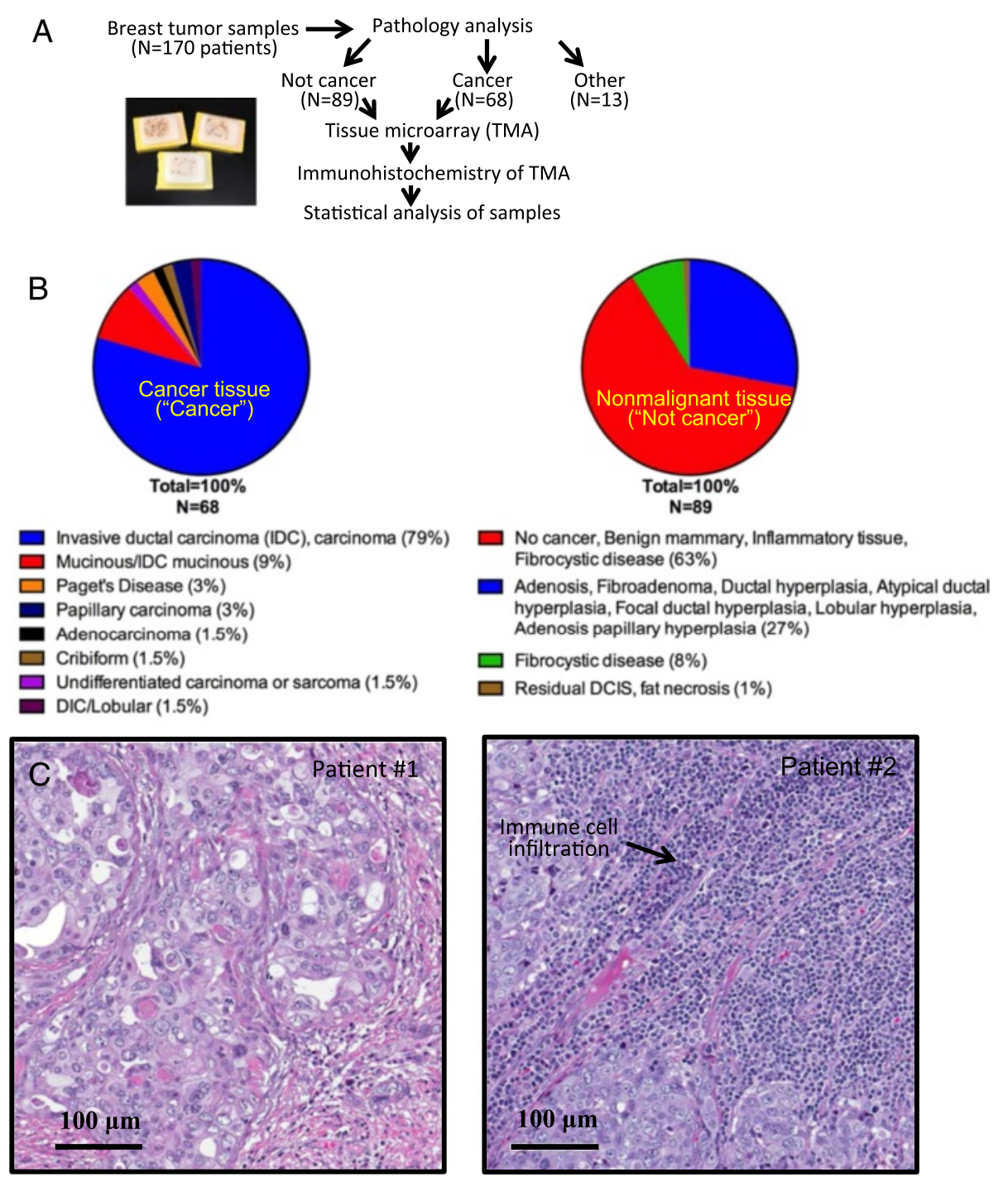

Fig. 1 Pathology of Kenyan breast cancer tissue samples. a Experimental design flowchart for this study. Samples were collected, analyzed for pathology, processed to create a tissue microarray, stained for clinical marker immunohistochemistry, and quantified by statistical analysis. $\mathbf{b}$ Pie chart representations of the distribution of cancer (left) and benign/not cancer (right) pathologies in Kenyan breast tissues analyzed after H\&E staining. Most of these patients were diagnosed with invasive ductal carcinoma (IDC) and mucinous IDC. Most benign samples fell into the category that includes benign mammary, inflammatory tissue, and fibrocystic disease. (C) H\&E staining of representative Kenyan breast cancer samples analyzed for pathology. Both Patient 1 and Patient 2 have invasive ductal carcinoma (IDC). Patient 2 has significant immune cell infiltration

We next stained TMA tissue sections by immunohistochemistry for estrogen receptor (ER) and progesterone receptor (PR) and scored the samples for positive expression of these receptors in the epithelium (Fig. 2a and Table 1 ). The majority of the cancers were ER positive (59\% ER positive vs. $41 \%$ ER negative) and PR negative (60\% PR negative vs. $40 \%$ PR positive). These rates are lower than those seen in western countries but could be a reflection of the cancers occurring in younger populations. To determine if the ER status was expected based on the age of the population, we statistically compared our dataset to another large breast cancer patient dataset (analysis described in Methods)
( $N=1992$ patients, METABRIC) [22]. Our analysis suggests that the differences in ER status of the two patient populations represented by the datasets likely are caused by the age difference in the two populations (i.e., the ER populations were not statistically different from each other; $P=0.11$ ). In addition, our model also confirms that the age of the patient population has a very significant influence on the ER status $\left(P<1 \times 10^{10}\right)$.

\section{Cohort of patients with triple negative and highly proliferative breast cancer}

We hypothesized that the western Kenyan cancers would also be enriched for triple negative breast 
cancer (HER2 negative, ER negative, PR negative). We compared the percentage of patients with triple negative breast cancer to the percentage of patients in other breast cancer studies. Indeed, we found a high representation (33\%) of triple negative breast cancer in the tissue samples (Table 1).

After determining the receptor status of the malignant samples, we next looked at proliferation in the non-cancer and cancer samples. Both cancer and non-cancer TMA tissue samples were stained for the proliferation marker Ki67 by immunohistochemistry and quantified for the percentage of Ki67 positive epithelial cells (Fig. 2b, c). The ER+ or ER- cancer tissues expressed more Ki67 positive cells than did the non-cancer samples. The following combinations were significantly higher in cancer samples compared to not cancer samples by one-sided $t$-test: $P=2.834 \mathrm{e}-05$ (ER+ vs. not cancer) and 4.576e-06 (ER- vs. not cancer), respectively. In addition, both ER+ and ERtumors expressed Ki67, with more proliferation in the ER- tumors than in the ER+ tumors $(P=0.0009$ by one-sided $t$-test to test if ER- is larger than ER+; $P=0.002$ by two-sided $t$-test to test if ER- is different from ER+). Because not only the ER- tumors but also the ER+ tumors expressed higher Ki67 than did not cancer tissue, this indicates that the tumors from the Kenyan patients are highly proliferative with a high grade.
Increased infiltration of CD163+ M2 macrophages, CD25+ $T$ regulatory cells, and CD4+ T helper cells, but not CD20+ B cells or CD8+ cytotoxic T cells, in Kenyan breast cancer tissue

Since the analysis of the pathology of these tumors identified a large number of tumors with inflammatory cell infiltration, we wanted to identify which kinds of inflammatory cells were recruited to the tumor microenvironment during breast cancer progression. Macrophages, B cells, and $\mathrm{T}$ cells are among the most common leukocytes found in the stroma of neoplastic breast tissue $[20,30]$. We stained the patient breast tissue samples for markers used to distinguish between these inflammatory cell types. We stained and scored patient tissue samples for CD68 (Fig. 3a, c), which is a macrophage marker, and CD163 (Fig. 3b, c), which stains M2 macrophages. The cancer tissue samples had increased CD68+ cells as well as increased M2 macrophage activation compared to the non-cancerous tissues. These results suggest that the cancer tissues have increased macrophage infiltration, marked by an increase in M2 macrophages.

To investigate the adaptive immune response in cancer, we stained and quantified the tissue samples for markers of both the cellular and humoral immune responses by immunohistochemistry. We stained tissues for CD4 ( $\mathrm{T}$ helper cells), CD8 (cytotoxic T cells), and CD20 (B cell marker). Cancer tissues had increased recruitment of CD4+ T helper cells (Fig. 4a, d). In contrast, CD20 and CD8 positive cells

Table 2 Comparison of breast cancer studies from East Africa

\begin{tabular}{|c|c|c|c|c|c|c|c|c|c|c|c|c|c|}
\hline Study & Country & City & $\begin{array}{l}\text { Patients with } \\
\text { Breast Cancer } \\
(\mathrm{N})^{\#}\end{array}$ & $\begin{array}{l}\text { Retrospective } \\
\text { or prospective } \\
\text { study design }\end{array}$ & $\begin{array}{l}\text { Female } \\
(\%)\end{array}$ & $\begin{array}{l}\text { Male } \\
\text { (\%) }\end{array}$ & $\begin{array}{l}\text { Ethnic groups } \\
\text { considered in } \\
\text { study }\end{array}$ & $\begin{array}{l}\text { Immune cells } \\
\text { quantified }\end{array}$ & $\begin{array}{l}\text { Median } \\
\text { age }\end{array}$ & $\begin{array}{l}\text { Mean } \\
\text { age }\end{array}$ & $\begin{array}{l}\text { ER+ } \\
(\mathrm{N})\end{array}$ & $\begin{array}{l}\text { ER- } \\
(\mathrm{N})\end{array}$ & $\begin{array}{l}\text { ER+ } \\
\text { (\%) } \\
\end{array}$ \\
\hline $\begin{array}{l}\text { This Study, } \\
\text { Sawe et al. }\end{array}$ & Kenya & Eldoret & $48(68)^{\mathrm{A}}$ & Prospective & 93 & 7 & Yes & $\begin{array}{l}\text { CD68, CD163, } \\
\text { CD4, CD8, } \\
\text { CD20, CD25 }\end{array}$ & 48.5 & 51.9 & 29 & 20 & 59 \\
\hline $\begin{array}{l}\text { Nalwoga } \\
\text { et al. }\end{array}$ & Uganda & Kampala & $65^{B}$ & Retrospective & 100 & no ${ }^{B}$ & No & None & & 49.8 & 23 & 42 & 35 \\
\hline Roy et al. & Uganda & Kampala & $35(45)^{B, C}$ & Retrospective & 96 & $4^{C, B}$ & No & None & & & 27 & 18 & 60 \\
\hline Bird et al. & Kenya & Kijabe & $34(129)^{\mathrm{D}}$ & Prospective & 97 & 3 & No & None & 47 & 48 & 29 & & 24 \\
\hline Nyagol et al. & Kenya & Nairobi & $158^{\mathrm{B}}$ & Prospective & 100 & no ${ }^{B}$ & No & None & & 47 & 59 & 99 & 37 \\
\hline Wata et al. & Kenya & Nairobi & $54(219)^{\mathrm{B}, \mathrm{E}}$ & Retrospective & 100 & no ${ }^{B}$ & No & WBC, platelets & 45 & 46.5 & 30 & 34 & 47 \\
\hline $\begin{array}{l}\text { Kantelhardt } \\
\text { et al. }\end{array}$ & Ethiopia & $\begin{array}{l}\text { Addis } \\
\text { Ababa }\end{array}$ & $352^{B}$ & Retrospective & 100 & no ${ }^{B}$ & No & None & & $40.1-43^{\mathrm{H}}$ & 230 & 122 & 65 \\
\hline Burson et al. & Tanzania & $\begin{array}{l}\text { Dar es } \\
\text { Salaam }\end{array}$ & $57(488)^{\prime}$ & Retrospective & 97 & 3 & No & None & & 49.4 & 33 & 32 & 51 \\
\hline
\end{tabular}

ER estrogen receptor, PR progesterone receptor, HER2 human epidermal growth factor, TN triple negative (ER-,PR-,HER2-), N number, \% = percent, n.d not determined

\#The number before the parentheses is the number of patients used for analysis of receptor status and is summarized individually by the indicated superscripts

The number in parentheses represents the total number of patients with breast cancer in the study.

${ }^{A} N=48$ patients with PR and triple negative data. $N=49$ with ER, HER2 data. Excluded patients who did not provide consent or who had chemotherapy prior to surgery

Bnly females included in study

$C_{N}=35$ patients with triple negative data. $N=44$ patients with HER2 data. 2 of 47 (4\%) patients were male but were excluded from the study

${ }_{N}=34$ patients with HER2/triple negative data. 120 patients with hormone receptor data

${ }^{E} N=54$ patients with HER2 data. $N=64$ patients with ER data. $N=64$ for PR. Excluded if $<18$ yrs old, male, or if chart did not have a date of diagnosis

Fo hormonal receptor data in this study

${ }^{G}$ Defined in this study by staining for Cytokeratin 5/6 and P-Cadherin as basal subtype markers, rather than ER, PR, and HER2

${ }^{H}$ Mean is 43 years old for ER+ and 40.1 years old for ER- patients

' $N=57$ patients with ER and PR data. No HER2 data for these patients 
Table 2 Comparison of breast cancer studies from East Africa (Continued)

\begin{tabular}{|c|c|c|c|c|c|c|c|c|c|c|c|c|c|}
\hline Study & $\begin{array}{l}\text { ER- } \\
(\%)\end{array}$ & $\begin{array}{l}\text { PRt } \\
(\mathrm{N})\end{array}$ & $\begin{array}{l}\text { PR- } \\
(\mathrm{N})\end{array}$ & $\begin{array}{l}\text { PR+ } \\
(\%)\end{array}$ & $\begin{array}{l}\text { PR- } \\
(\%)\end{array}$ & $\begin{array}{l}\text { HER2+ } \\
\text { (N) }\end{array}$ & $\begin{array}{l}\text { HER2- } \\
(\mathrm{N})\end{array}$ & $\begin{array}{l}\text { HER2+ } \\
\text { (\%) }\end{array}$ & $\begin{array}{l}\text { HER2- } \\
(\%)\end{array}$ & $\begin{array}{l}\text { TN } \\
(\mathrm{N})\end{array}$ & $\begin{array}{l}\text { TN } \\
(\%)\end{array}$ & $\begin{array}{l}\text { Time Period of } \\
\text { Sample Collection }\end{array}$ & $\begin{array}{l}\text { Date of } \\
\text { Publication }\end{array}$ \\
\hline $\begin{array}{l}\text { This Study, } \\
\text { Sawe et al. }\end{array}$ & 41 & 19 & 29 & 40 & 60 & 7 & 42 & 14 & 86 & 16 & 33 & 2011-2013 & \\
\hline $\begin{array}{l}\text { Nalwoga } \\
\text { et al. }\end{array}$ & 65 & 15 & 50 & 23 & 77 & 19 & 46 & 29 & 71 & & $34^{G}$ & $1993-2002$ & 2007 \\
\hline Roy et al. & 40 & & & & & 5 & 39 & 11 & 89 & 16 & 36 & $2000-2004$ & 2011 \\
\hline Bird et al. & & & & & & 9 & 25 & 26 & 74 & 15 & 44 & $2001-2007$ & 2008 \\
\hline Nyagol et al. & 63 & 77 & 81 & 49 & 51 & 44 & 114 & 28 & 72 & 44 & 28 & $2002-2004$ & 2006 \\
\hline Wata et al. & 53 & 28 & 36 & 44 & 56 & 19 & 35 & 35 & 65 & & & 2007-2008 & 2013 \\
\hline $\begin{array}{l}\text { Kantelhardt } \\
\text { et al. }\end{array}$ & 35 & 176 & 168 & 51 & 49 & n.d. & n.d. & n.d. & n.d. & & & $2005-2010$ & 2014 \\
\hline Burson et al. & 49 & 29 & 36 & 45 & 55 & n.d. & n.d. & n.d. & n.d. & & & 2009-2010 & 2010 \\
\hline
\end{tabular}

were not differentially recruited to cancer versus noncancer tissues (Fig. 4b-d).

Mature CD8+ T cells are cytotoxic effectors of the immune system that support antitumor activity and correlate with improved prognosis in breast cancer patients [31]. Because the CD8-mediated immune response was not sufficient to overcome the cancer cells in these patients, we hypothesized that the tumors developed an alternative strategy to overcome the cytotoxic activity of CD8+ T cells. Examples of immunosuppressive strategies used by tumor cells to escape immune surveillance include elevated activity of Treg cells to inhibit antitumor immune response, upregulation of CTLA-4 and PD-L1; TGF- $\beta$ production; and loss of $\mathrm{T}$ cell antigen presentation in the tumor (reviewed in [32]).

We examined the infiltration of $\mathrm{CD} 25+$ regulatory $\mathrm{T}$ cells (Tregs) into the tumor. A primary function of CD25+ Tregs is to inhibit the antitumor activity of CD8+ cytotoxic T cells [31]. Also, M2 macrophages, which are increased in these tumors (Fig. 3), can recruit Tregs [33]. We looked at the recruitment of Tregs by immunostaining the tissue samples for CD25. Interestingly, we saw an increase in the number of CD25+ cells recruited to the cancer compared to the non-cancer tissues (Fig. 5a, b). These data suggest that CD25+ Tregs are recruited to breast malignancies in a subset of the western Kenyan patient cohort and may impair their immune response to tumors in these patients.

\section{Discussion}

In this prospective study, we characterized breast cancer tissue samples collected from consecutive patients of western Kenya. We found that a high percentage of these patients were diagnosed with cancer at a young age and developed a low three-year survival rate. The majority (59\%) of the breast tumors expressed estrogen receptor, while $33 \%$ of the tumors were triple negative. The breast tumors were highly proliferative and high grade invasive ductal carcinomas with immune cell infiltration. The immune cells recruited to the tumor included cells expressing markers CD68, CD163, CD4, and CD25. Because a western Kenyan breast cancer patient population has not been studied previously, this study has important implications for identifying appropriate treatment strategies that are required to reduce mortality of Kenyan breast cancer patients, who currently have limited diagnostic and treatment opportunities.

\section{Estrogen receptor status}

Though the majority of the breast tumors from our patient cohort were $\mathrm{ER}+$, roughly $33 \%$ of the breast cancer patients in our study had triple negative breast tumors, which also are indicative of poor prognosis. These results are consistent with other studies that find that $23 \%-44 \%$ of breast cancer tissue samples collected from East African women in Kenya, Ethiopia, and Uganda are triple negative [17, 19, 25-27, 34]. African women with breast cancer also have a higher prevalence of ER- and triple negative cancer compared with Caucasian populations [6, 14, 19, 34, 35]. These results also are similar to that seen in breast tumors from black women in the U.S. and in the United Kingdom, as compared to white women, where the patient cohorts also had a high representation of triple negative/basal subtype breast tumors $[36,37]$.

\section{Treatment of breast cancer in Western Kenya}

Testing for ER status is not a standard test for breast cancer treatment in Kenya but would provide a significant advancement in directing the treatment strategy of these patients. When markers have been used to direct chemotherapy and hormone therapies as treatment strategies, the patients have had improved 


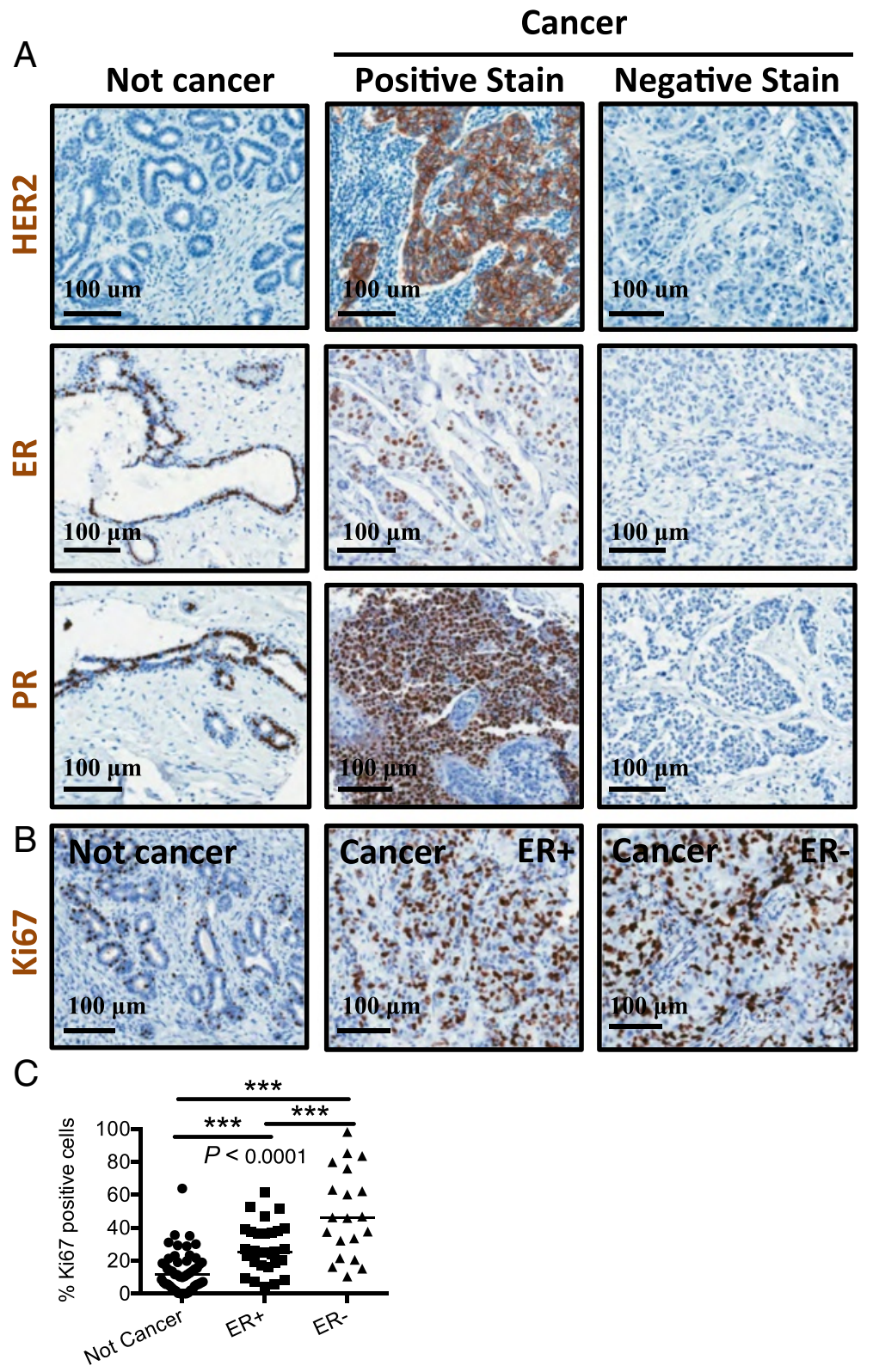

Fig. 2 Heterogeneous expression of ER, PR, and HER2 receptors and increased proliferation. a Representative tissue samples from cancer and not cancer tissues that were stained for HER2, ER, and PR receptor expression. Examples of tissue that stained positively and negatively for the receptors are included. b Representative cancer and not cancer samples stained for the Ki67 proliferation marker. c Data plot analysis of Ki67 positive cells in ER+ vs. ER- tissue samples. Ki67 staining is significantly different between tissues from not cancer, ER+, and ER- breast samples $(P<0.0001$, ANOVA) in ER- tissue samples, indicating high grade and an increase in cellular proliferation. The following combinations were significantly different by one-sided t-test: $P=2.834 \mathrm{e}-05$ (ER+ vs. not cancer), 4.576e-06 (ER- vs. not cancer), and $P=0.0009$ (ER- vs. ER+). The bar represents the median of all samples in the indicated cohort and includes any unstained samples

survival and reduced metastasis rates [28]. Unfortunately, because of limited resources in Kenya, clinical marker testing and treatments for these patients are particularly challenging $[1,6]$.

Since the majority of the tumors in this study were ER+, this suggests that the majority of these western Kenyan patients are candidates for treatment with hormone therapy, such as tamoxifen, fulvestrant, or aromatase inhibitors.
In contrast, since almost all ER-tumors were triple negative, the patients with ER-tumors instead should be treated with chemotherapy and/or radiation. However, the lack of facilities for chemotherapy and radiation make it imperative that efforts should be focused on early detection by community education and screening. For example, Moi Teaching and Referral Hospital in Eldoret, Kenya, where this study was initiated, has standard of care for breast 

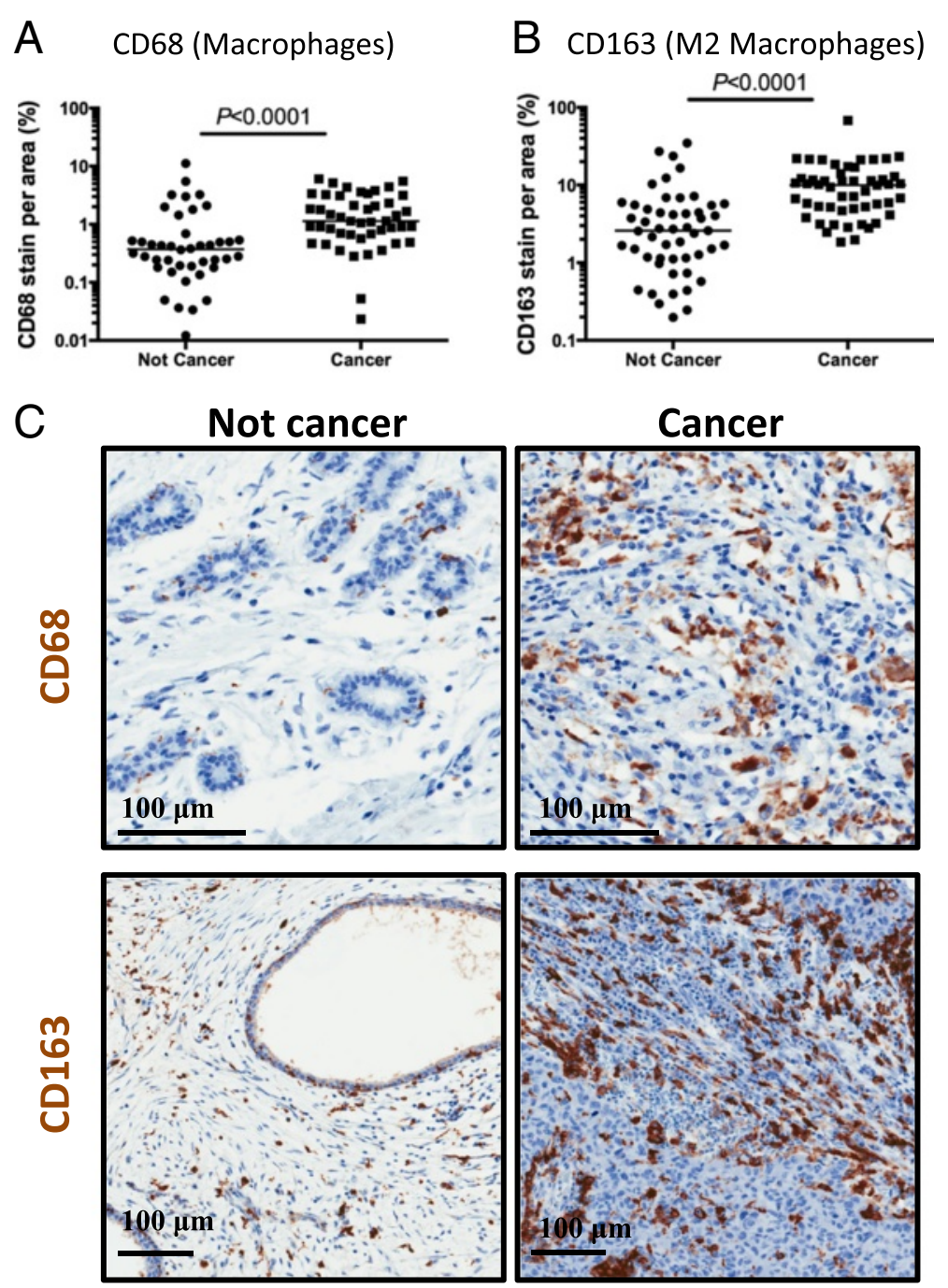

Fig. 3 Kenyan breast cancer tissue samples have increased macrophage infiltration in primary breast tumors. a Data plot analysis of IHC analysis for the macrophage lineage utilizing a CD68 antibody. Quantitative analysis of the staining indicates a significant increase in percent of CD68+ stained area $(P<0.0001$; Mann-Whitney). b Data plot of IHC analysis for the M2 macrophage lineage utilizing a CD163 antibody. Quantitative analysis of the IHC staining revealed a significant increase in percent of CD163 stained area ( $P \leq 0.0001$; Mann-Whitney) in M2 macrophages in cancerous Kenyan breast tissues versus noncancerous Kenyan breast tissues. c Immunohistochemistry of representative noncancer and cancer samples for both general macrophage lineage (CD68) and the M2 macrophage lineage (CD163). Because the graphs are a log scale, any samples with unstained sections (i.e., zero) are not included in the graph. The bar represents the median of all samples in the indicated cohort and includes any unstained samples

cancer patients that predominantly includes surgical procedures/mastectomy and chemotherapy (personal observation). Because this hospital currently does not have a radiotherapy machine, radiotherapy is not even an option for these patients without additional resources and significant travel [38].

Ethnic groups and regional differences in Western Kenya Our study uniquely includes ethnic group information on its patient population. The breast cancer patients in this study have a different genetic background from population in other regions throughout Kenya based on the ethnic population data. The Uasin Gishu County website suggests that this county is "largely a cosmopolitan region, with the Nandi people of indigenous Kalenjin communities having the highest settlement." Similar to the county data, the patients from MTRH in our study are predominantly in two ethnic groups: Luyha (38 \%) and Kalenjin (34\%). In contrast, nationally the Kikuyu ethnic group is ranked first (22\%), followed by Luhya (14\%), and Kalenjin (12\%). No ethnic group data were included in the other breast cancer studies including patients from East Africa. However, the Nairobi ethnic group demographics differ from Eldoret ethnic group demographics and likely are reflected in their patient populations. 


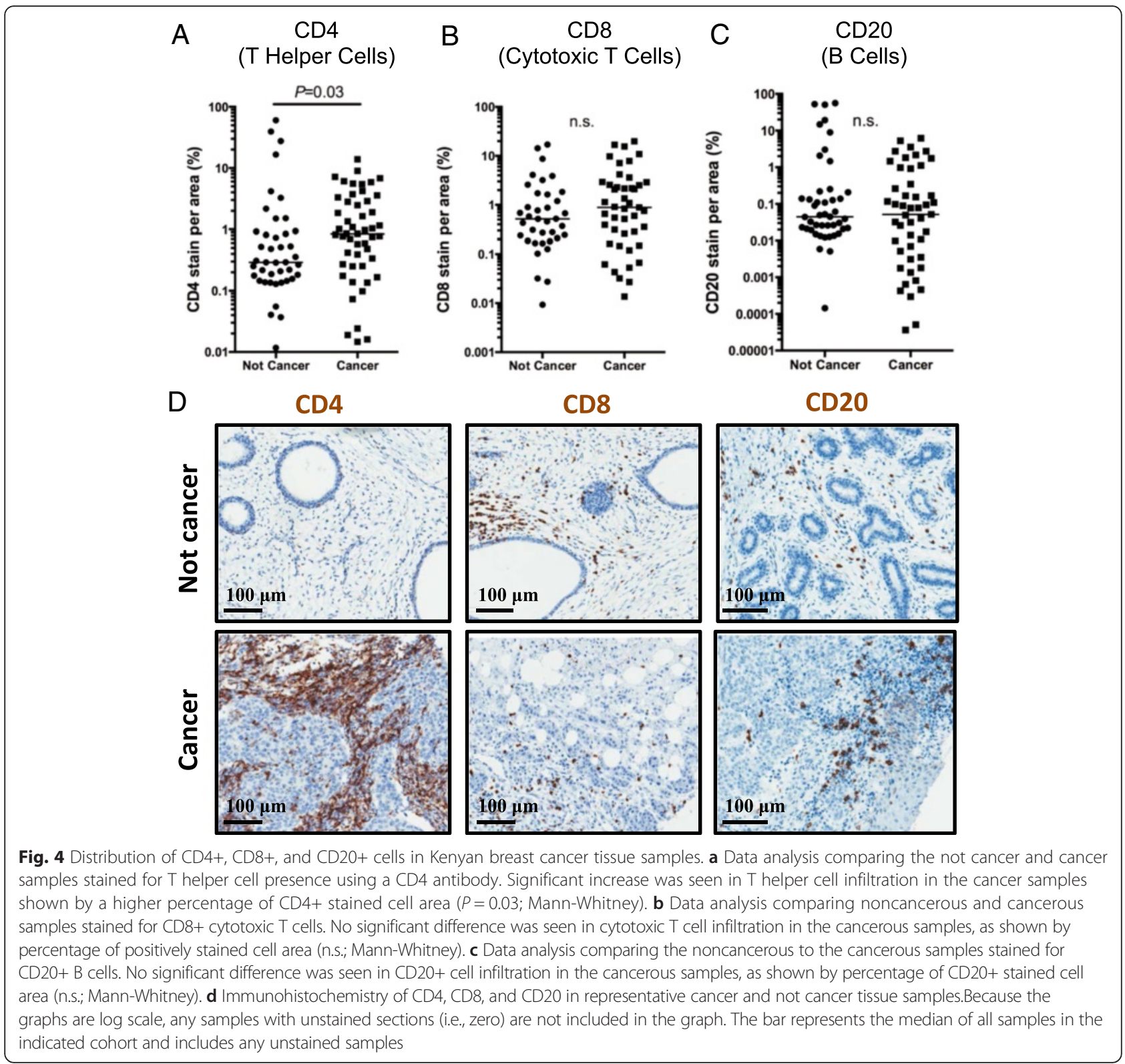

\section{Male breast cancer}

We uniquely included men who developed breast cancer in the analysis of our study and found a rate of $7 \%$ male breast cancer. This rate of male breast cancer is very high and is unusual. While most of the studies on East Africa patients excluded male patients from their analysis [17, 25-28], three other East Africa studies reported a high rate of male breast cancer (3-4\%) but have a lower rate compared to our study $[19,26,29]$. The percentage of male breast cancer patients was significantly different from other large breast cancer population studies from Tunisia, Nigeria, and the United States (Additional file 2: Table S2). This suggests that the high percentage of male patients in Eldoret patients is unlikely due to chance alone.

\section{Immune cell infiltration}

To our knowledge, before this study, immune cell distribution by immunohistochemistry has not been studied in any other patient cohorts from Africa, making this study significant. Infiltration of macrophages, B cells, and $\mathrm{T}$ cells often increases with and are required for pathological breast cancer progression (reviewed in $[20,31,39,40])$. Infiltration of mouse breast tumors with macrophages leads to an increase in breast cancer progression and lung metastasis, while depleting macrophages reduces them [40]. In addition, transgenic mouse models of breast cancer that are deficient in CD4+ cells initially developed primary tumors at similar rates but developed lung metastasis at a lower 

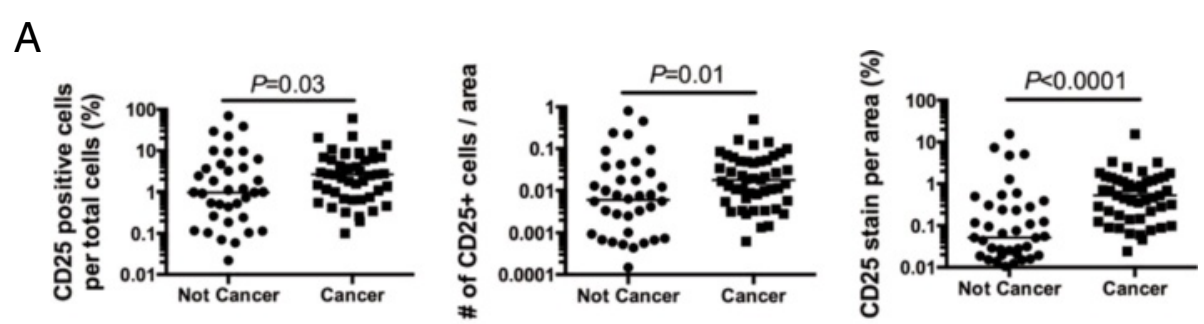

B
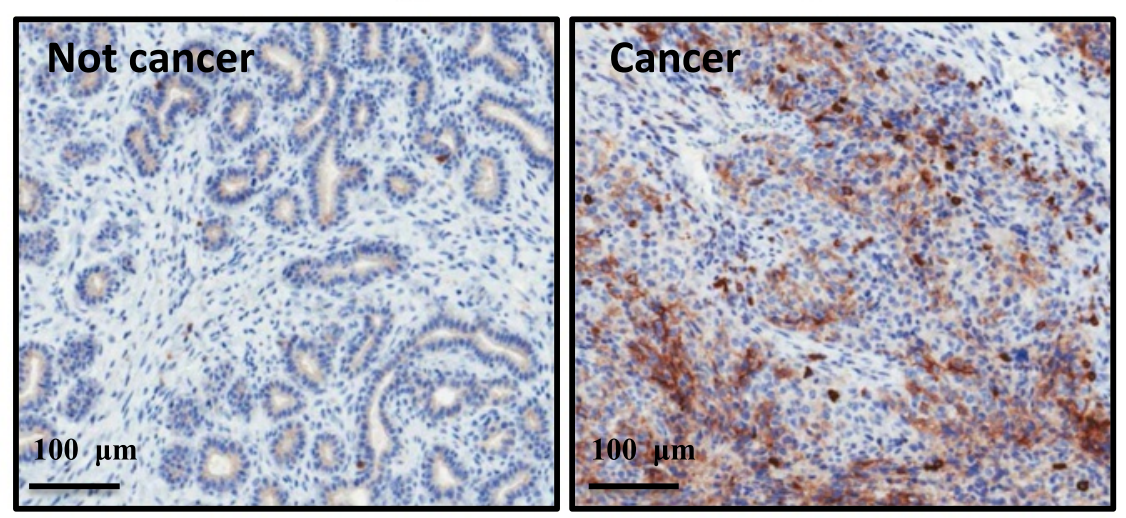

\section{CD25 (Regulatory T Cells)}

C

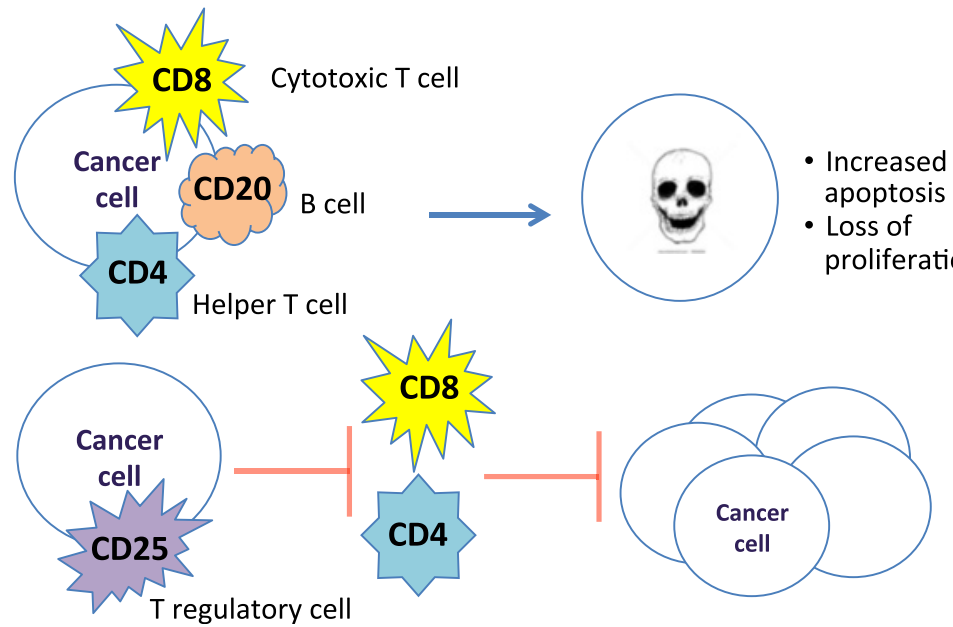

Fig. 5 Increased infiltration of regulatory T cells in Kenyan breast cancer tissue. a Data analysis comparing the noncancerous and cancerous samples stained for CD25+ regulatory T cells. A significant increase was seen in regulatory $T$ cell infiltration in the cancer samples, as shown by a higher percentage of positively stained cells $(P=0.03$; Mann-Whitney), increased number of positively stained cells per area ( $P=0.01$; Mann-Whitney), and a higher percentage of CD25 stain per area $(P=0.0001$; Mann-Whitney). Because the graph is a log scale, any samples with unstained sections (i.e., zero) are not included in the graph. The bar represents the median of all samples in the indicated cohort and includes any unstained samples. b Representative cancer and not cancer tissue samples stained for CD25. c Proposed T cell mechanism of action in Kenyan breast cancer model. (Top) Without a strong presence of regulatory T cells (e.g., benign Kenyan tissue), cytotoxic and T helper cells are able to combat and suppress the cancer cell, leading to increased apoptosis and loss of proliferation. (Bottom) When T regulatory cells are present (e.g., Kenyan breast cancer tissue), they block cytotoxic and helper T cells from fighting off the cancer cells

frequency than wildtype mice, suggesting that $\mathrm{CD} 4+\mathrm{T}$ cells are required for breast cancer during lung metastasis [20]. These leukocytes also contribute to therapeutic response. Interestingly, cytotoxic drugs themselves can trigger tumor cells to release macrophage/monocyte recruitment factors, which in turn promote the infiltration of tumor-associated macrophages to the tumor cells. In addition, when macrophage recruitment is blocked with antagonists to colony stimulating factor 1 receptor (CSF1R) and in combination with paclitaxel, this treatment causes both an increase in primary breast tumor and lung metastasis as well as increased tumor suppression that was CD8+ CTL cytotoxic T cell-dependent [39]. 
In our study, the breast cancer tissue samples tested had increased $\mathrm{T}$ cell and macrophage immune cell marker (CD4, CD25, CD63, CD163) expression compared to benign tissue. M2 macrophages (CD163+) and regulatory $\mathrm{T}$ cells $(\mathrm{CD} 25+)$ in particular are associated with protumor roles during breast cancer progression. In fact, M2 macrophages and Tregs have a complimentary and synergistic relationship to promote their plasticity [41]. Tregs can differentiate monocytes/macrophages into CD163+ M2 macrophages [42]. M2 macrophages also can secrete chemokines that promote the induction, differentiation, and recruitment of Tregs [33].

In normal tissues, Tregs prevent autoimmune responses; in tumors, Tregs prevent the destruction of tumors by CD8+ cytotoxic T cells and contribute to cancer cells evading their detection by the immune system (Fig. 5c) [31]. Moreover, infiltration of Tregs into breast tumors is prognostic of reduced survival in patients [21]. Conversely, therapeutic strategies that eliminate the Tregs to modulate Treg activity (e.g., anti-CD25 mAb and CTLA-4 antagonists) have had some success in treating melanoma patients [43]. The Kenyan cancer patients with tumors that express high CD25+ cells might benefit from a similar therapeutic strategy designed to overcome the inhibitory immune response and to improve the anti-tumor immune response for patients with high levels of Tregs within the tumor site. Future research will be required to determine if immune modulators that eliminate Tregs or increase tumor destruction by CD8+ T cells will help in overcoming the aggressive breast cancer seen in Kenya.

\section{Patient population of this study}

With our current sample size, our study identified both clinical features (e.g., male breast cancer, young age at presentation, estrogen receptor status) and immune cell features of this patient population that are worthy of additional studies. Our breast cancer patient sample size that was used for hormone receptor status $(N=48$ breast cancer tissue with known hormone receptor status of breast cancer of 68 total patients) is comparable to other breast cancer studies from Kenya, Uganda, and Tanzania: $(N=34$ with hormone receptor status of 129 total patients; [19]); ( $N=54$ with hormone receptor status of 219 total patients; [28]); $(N=158$; [27]); $(N=35$ patients with hormone receptor status of 45 total patients enrolled in study; [26]); $(N=65 ;[25]) ;$ and $(N=57$ with hormone receptor status of 488 total patients; [29]). In fact, a large meta-analysis of African breast cancer studies that included receptor status did not find a small study bias that affected the receptor status in the studies analyzed from sub-Saharan Africa, which includes Kenya [44].

Of the studies mentioned above, only two were prospective studies [19, 27]. Older retrospective samples trended to have a lower percentage of ER+ tumors compared to prospective studies [44]. In a meta-analysis of studies from Sub-Sahara Africa, tumor tissue samples from retrospective studies included $10 \%$ less ER+ tumors compared to prospective studies, suggesting increased bias in retrospective studies [44]. Our study was strengthened by being a prospective study and by not being a convenience sample.

\section{Changing landscape of breast cancer in Africa}

Between 1980-2010, breast cancer incidence and death increased in Kenya and throughout Africa [2]. The cause of this increase in breast cancer is unknown but is speculated to be associated with risk factors, such as obesity, the increased awareness and detection of breast cancer, and the aging population $[2,3,6]$. However, an environmental factor that contributes to the aggressive nature of the disease progression would also be consistent with the results of our study, which include the young age at the presentation of the disease, the high percentage of males with breast cancer, and the suppressed antitumor immune response.

Interestingly, in contrast to our study, the prevalence of ER-negative breast cancer in East African-born blacks who immigrate to the U.S. is similar to the prevalence seen in U.S.-born whites [23]. However, the study's East African-born population primarily was born in Ethiopia or Eritrea and may not represent the western Kenya patient population in our study. In contrast to this East African-born population, the ER-negative breast cancer in West African-born blacks is similar to the prevalence in U.S.-born black women. This finding suggests differences in the disease progression between black populations born in West or East Africa. Because these differences are not apparent when populations remain in Africa, the differences in prevalence are likely to be caused by a combination of environmental and genetic factors. Because of the small number of patients who donated detailed clinical data, our study is inconclusive to determine if these factors impact or affect the risk of breast cancer in Kenyan breast cancer. In future studies, we will track these patients over time to define more clearly which patients have the worst prognosis. Such studies will be important to identify the mortality rate of the patients, since many countries, including those in sub-Saharan Africa, do not have complete mortality data and instead must estimate mortality rates [2].

\section{Conclusions}

Our data suggest that the breast cancer developing in patients of western Kenya is aggressive and is associated with diagnosis at a young age, high proliferative index and high immune cell infiltration in the primary tumors, and poor three-year patient survival. Our characterization of 
this patient population using clinical markers suggests possible treatment strategies that will be effective in improving the outcome for these patients. This research enhances our ability to diagnose and treat breast cancer patients in Kenya. In addition, achievements in our understanding of the etiology and treatment of a unique population of Kenyan patients with aggressive breast cancer may help identify and treat other poor prognostic breast cancers from other populations with a similar cancer disease progression.

\section{Additional files}

Additional file 1: Table S1. Antibodies used in this study. (PDF $42 \mathrm{~kb}$ )

Additional file 2: Table S2. Comparison of gender rates in breast cancer patients of Eldoret, Kenya and other regions. (PDF 73 kb)

\section{Abbreviations \\ ER: estrogen receptor; Her2/neu receptor HER2: human epidermal growth factor 2 receptor; IHC: immunohistochemistry; MTRH: Moi Teaching and Referral Hospital; PR: progesterone receptor; TMAs: tissue microarrays; Tregs: regulatory $\mathrm{T}$ cells.}

\section{Competing interests}

The authors declare that they have no competing interests.

\section{Author contributions}

RT collected the tissue samples and the clinical data. RT, SB, JP, AO, KT, MSS, SM, and LEL. made substantial contributions to the conception and design of this project. MK and RT embedded the tissues, made the tissue microarrays, and sectioned the tissues. MS, MK, and ZS. scanned, collected data, and took pictures using Aperio. SB led the pathology analysis. DC and ZS also analyzed the pathology of the tumors. JL, SX, and LEL did all of the statistical analysis. MK and LEL built the figures. LEL analyzed and interpreted the quantitative data. MK, SX, and LEL wrote the manuscript. RT, MK, SB, JL, MS, JP, SX, ZS, MSS, and LEL critically revised the manuscript. All authors read and approved the final manuscript.

\section{Acknowledgements}

This work was supported by grant support from the Walther Foundation and the St. Joseph Regional Medical Center as well as institutional support from Harper Cancer Research Institute, Eck Institute for Global Health, University of Notre Dame, Moi University Teaching and Referral University, and Maseno University. LEL is supported by an Indiana CTSI Young Investigator Award and a grant from the Mary Kay Foundation. Special thanks to Emilia Hartland, Katherine Taylor, Lacey Haussamen, Andy Bullock, the Eck Institute for Global Health, and the Harper Cancer Research Institute for ongoing support and encouragement; Laura Tarwater and the Harper Cancer Research Institute Tissue Biorepository; and Frank Castellino, Victoria Ploplis, and the University of Notre Dame W. M. Keck Center for Transgene Research for offering initial histological support.

\section{Author details}

${ }^{1}$ University of Notre Dame, Notre Dame, IN, USA. ${ }^{2}$ Harper Cancer Research Institute, University of Notre Dame, 1234 N Notre Dame Avenue, South Bend, IN, USA. ${ }^{3}$ Moi University, Eldoret, Kenya. ${ }^{4}$ Maseno University, Maseno, Kenya. ${ }^{5}$ Indiana University School of Medicine, Indianapolis, IN, USA. ${ }^{6}$ Eck Institute for Global Health, Notre Dame, IN, USA. ${ }^{7}$ Indiana University School of Medicine-South Bend, South Bend, IN, USA.

Received: 29 November 2015 Accepted: 17 February 2016 Published online: 10 March 2016

\section{References}

1. Jemal A, Bray F, Center MM, Ferlay J, Ward E, Forman D. Global cancer statistics. CA Cancer J Clin. 2011;61(2):69-90.
2. Forouzanfar MH, Foreman KJ, Delossantos AM, Lozano R, Lopez AD, Murray CJ, Naghavi M. Breast and cervical cancer in 187 countries between 1980 and 2010: a systematic analysis. Lancet. 2011;378(9801):1461-84.

3. Parkin DM, Bray F, Ferlay J, Jemal A. Cancer in Africa 2012. Cancer Epidemiol Biomark Prev. 2014;23(6):953-66.

4. Anderson BO, Shyyan R, Eniu A, Smith RA, Yip CH, Bese NS, Chow LW, Masood S, Ramsey SD, Carlson RW. Breast cancer in limited-resource countries: an overview of the Breast Health Global Initiative 2005 guidelines. Breast J. 2006;12 Suppl 1:S3-15.

5. Eniu A, Carlson RW, Aziz Z, Bines J, Hortobagyi GN, Bese NS, Love RR, Vikram $\mathrm{B}$, Kurkure $\mathrm{A}$, Anderson $\mathrm{BO}$, et al. Breast cancer in limited-resource countries: treatment and allocation of resources. Breast J. 2006;12 Suppl 1:S38-53.

6. Fregene A, Newman LA. Breast cancer in sub-Saharan Africa: how does it relate to breast cancer in African-American women? Cancer. 2005;103(8):1540-50.

7. DeSantis C, Ma J, Bryan L, Jemal A. Breast cancer statistics, 2013. CA Cancer J Clin. 2014;64(1):52-62.

8. Chu KC, Anderson WF. Rates for breast cancer characteristics by estrogen and progesterone receptor status in the major racial/ethnic groups. Breast Cancer Res Treat. 2002;74(3):199-211.

9. Silber JH, Rosenbaum PR, Clark AS, Giantonio BJ, Ross RN, Teng Y, Wang M, Niknam BA, Ludwig JM, Wang W, et al. Characteristics associated with differences in survival among black and white women with breast cancer. JAMA. 2013;310(4):389-97.

10. lqbal J, Ginsburg O, Rochon PA, Sun P, Narod SA. Differences in breast cancer stage at diagnosis and cancer-specific survival by race and ethnicity in the United States. JAMA. 2015;313(2):165-73.

11. Sineshaw HM, Gaudet M, Ward EM, Flanders WD, Desantis C, Lin CC, Jemal A. Association of race/ethnicity, socioeconomic status, and breast cancer subtypes in the National Cancer Data Base (2010-2011). Breast Cancer Res Treat. 2014;145(3):753-63.

12. Gukas ID, Girling AC, Mandong BM, Prime W, Jennings BA, Leinster SJ. A comparison of clinicopathological features and molecular markers in british and nigerian women with breast cancer. Clin Med Oncol. 2008;2:347-51.

13. Gukas ID, Jennings BA, Mandong BM, Igun GO, Girling AC, Manasseh AN, Ugwu BT, Leinster SJ. Clinicopathological features and molecular markers of breast cancer in Jos, Nigeria. West Afr J Med. 2005;24(3):209-13.

14. Huo D, Ikpatt F, Khramtsov A, Dangou JM, Nanda R, Dignam J, Zhang B, Grushko T, Zhang C, Oluwasola O, et al. Population differences in breast cancer: survey in indigenous African women reveals over-representation of triple-negative breast cancer. J Clin Oncol. 2009;27(27):4515-21.

15. Adebamowo CA, Famooto A, Ogundiran TO, Aniagwu T, Nkwodimmah C, Akang EE. Immunohistochemical and molecular subtypes of breast cancer in Nigeria. Breast Cancer Res Treat. 2008;110(1):183-8.

16. Balko JM, Giltnane JM, Wang K, Schwarz LJ, Young CD, Cook RS, Owens P, Sanders ME, Kuba MG, Sanchez V, et al. Molecular profiling of the residual disease of triple-negative breast cancers after neoadjuvant chemotherapy identifies actionable therapeutic targets. Cancer Dis. 2014;4(2):232-45.

17. Kantelhardt EJ, Mathewos A, Aynalem A, Wondemagegnehu T, Jemal A, Vetter M, Knauf E, Reeler A, Bogale S, Thomssen C, et al. The prevalence of estrogen receptor-negative breast cancer in Ethiopia. BMC Cancer. 2014;14:895.

18. Nishimukai A, Yagi T, Yanai A, Miyagawa Y, Enomoto Y, Murase K, Imamura M, Takatsuka Y, Sakita I, Hatada T, et al. High Ki-67 expression and Low progesterone receptor expression could independently lead to a worse prognosis for postmenopausal patients with estrogen receptor-positive and HER2-negative breast cancer. Clin Breast Cancer. 2015;15(3):204-11.

19. Bird PA, Hill AG, Houssami N. Poor hormone receptor expression in East African breast cancer: evidence of a biologically different disease? Ann Surg Oncol. 2008;15(7):1983-8.

20. DeNardo DG, Barreto JB, Andreu P, Vasquez L, Tawfik D, Kolhatkar N, Coussens LM. CD4(+) T cells regulate pulmonary metastasis of mammary carcinomas by enhancing protumor properties of macrophages. Cancer Cell. 2009;16(2):91-102.

21. Bates GJ, Fox SB, Han C, Leek RD, Garcia JF, Harris AL, Banham AH. Quantification of regulatory $T$ cells enables the identification of high-risk breast cancer patients and those at risk of late relapse. J Clin Oncol. 2006;24(34):5373-80.

22. Curtis C, Shah SP, Chin SF, Turashvili G, Rueda OM, Dunning MJ, Speed D, Lynch AG, Samarajiwa S, Yuan Y, et al. The genomic and transcriptomic architecture of 2,000 breast tumours reveals novel subgroups. Nature. 2012;486(7403):346-52 
23. Jemal A, Fedewa SA. Is the prevalence of ER-negative breast cancer in the US higher among Africa-born than US-born black women? Breast Cancer Res Treat. 2012;135(3):867-73.

24. Siegel R, Ma J, Zou Z, Jemal A. Cancer statistics, 2014. CA Cancer J Clin. 2014;64(1):9-29.

25. Nalwoga $H$, Arnes JB, Wabinga $H$, Akslen LA. Frequency of the basal-like phenotype in African breast cancer. APMIS. 2007;115(12):1391-9.

26. Roy I, Othieno E. Breast carcinoma in Uganda: microscopic study and receptor profile of 45 cases. Arch Pathol Lab Med. 2011;135(2):194-9.

27. Nyagol J, Nyong'o A, Byakika B, Muchiri L, Cocco M, de Santi MM, Spina D, Bellan C, Lazzi S, Kostopoulos I, et al. Routine assessment of hormonal receptor and Her-2/neu status underscores the need for more therapeutic targets in Kenyan women with breast cancer. Anal Quant Cytol Histol. 2006;28(2):97-103.

28. Wata DE, Osanjo GO, Oluka M, Guantai AN. Predictors of breast cancer treatment outcomes in Kenyan women. African J Pharmacol Ther. 2013;2(4):109-15.

29. Burson AM, Soliman AS, Ngoma TA, Mwaiselage J, Ogweyo P, Eissa MS, Dey S, Merajver SD. Clinical and epidemiologic profile of breast cancer in Tanzania. Breast Dis. 2010;31(1):33-41.

30. Ruffell B, Au A, Rugo HS, Esserman LJ, Hwang ES, Coussens LM. Leukocyte composition of human breast cancer. Proc Natl Acad Sci U S A. 2012;109(8):2796-801.

31. DeNardo DG, Coussens LM. Inflammation and breast cancer. Balancing immune response: crosstalk between adaptive and innate immune cells during breast cancer progression. Breast Cancer Res. 2007;9(4):212.

32. Vesely MD, Kershaw MH, Schreiber RD, Smyth MJ. Natural innate and adaptive immunity to cancer. Annu Rev Immunol. 2011;29:235-71.

33. Savage ND, de Boer T, Walburg KV, Joosten SA, van Meijgaarden K, Geluk A, Ottenhoff TH. Human anti-inflammatory macrophages induce Foxp3+ GITR+ CD25+ regulatory $T$ cells, which suppress via membrane-bound TGFbeta-1. J Immunol. 2008;181(3):2220-6.

34. Trinkaus ME, Sayed S, Gakinya SM, Moloo Z, Hanna W, Rahim Y. Triple negative and basal-like breast cancer in East Africa. Breast J. 2011;17(4):438-40.

35. Stark A, Kleer CG, Martin I, Awuah B, Nsiah-Asare A, Takyi V, Braman M, Quayson SE, Zarbo R, Wicha M, et al. African ancestry and higher prevalence of triple-negative breast cancer: findings from an international study. Cancer. 2010;116(21):4926-32

36. Bowen RL, Duffy SW, Ryan DA, Hart IR, Jones JL. Early onset of breast cancer in a group of British black women. Br J Cancer. 2008:98(2):277-81.

37. Carey LA, Perou CM, Livasy CA, Dressler LG, Cowan D, Conway K, Karaca G, Troester MA, Tse CK, Edmiston S, et al. Race, breast cancer subtypes, and survival in the Carolina Breast Cancer Study. JAMA. 2006;295(21):2492-502.

38. Lesiew K, Alal M, Mghenyi C. Kenyan women flock to Uganda for cancer treatment. Nairobi: The Star; 2013.

39. DeNardo DG, Brennan DJ, Rexhepaj E, Ruffell B, Shiao SL, Madden SF, Gallagher WM, Wadhwani N, Keil SD, Junaid SA, et al. Leukocyte complexity predicts breast cancer survival and functionally regulates response to chemotherapy. Cancer Dis. 2011;1(1):54-67.

40. Lin EY, Nguyen AV, Russell RG, Pollard JW. Colony-stimulating factor 1 promotes progression of mammary tumors to malignancy. J Exp Med. 2001;193(6):727-40.

41. Biswas SK, Mantovani A. Macrophage plasticity and interaction with lymphocyte subsets: cancer as a paradigm. Nat Immunol. 2010;11(10):889-96.

42. Tiemessen MM, Jagger AL, Evans HG, van Herwijnen MJ, John S, Taams LS. CD4 + CD25 + Foxp3+ regulatory T cells induce alternative activation of human monocytes/macrophages. Proc Natl Acad Sci U S A. 2007;104(49):19446-51.

43. Shiao SL, Ganesan AP, Rugo HS, Coussens LM. Immune microenvironments in solid tumors: new targets for therapy. Genes Dev. 2011;25(24):2559-72.

44. Eng A, McCormack V, dos-Santos-Silva I. Receptor-defined subtypes of breast cancer in indigenous populations in Africa: a systematic review and meta-analysis. PLoS Med. 2014;11(9):e1001720.

\section{Submit your next manuscript to BioMed Central and we will help you at every step:}

- We accept pre-submission inquiries

- Our selector tool helps you to find the most relevant journal

- We provide round the clock customer support

- Convenient online submission

- Thorough peer review

- Inclusion in PubMed and all major indexing services

- Maximum visibility for your research

Submit your manuscript at www.biomedcentral.com/submit
Biomed Central 